\title{
Specify Other KRAS Codon 13 Mutation
}

National Cancer Institute

\section{Source}

National Cancer Institute. Specify Other KRAS Codon 13 Mutation. NCI Thesaurus. Code C158934.

A request to enter the specific KRAS codon 13 mutation that was identified in the study but is not present in the form. 